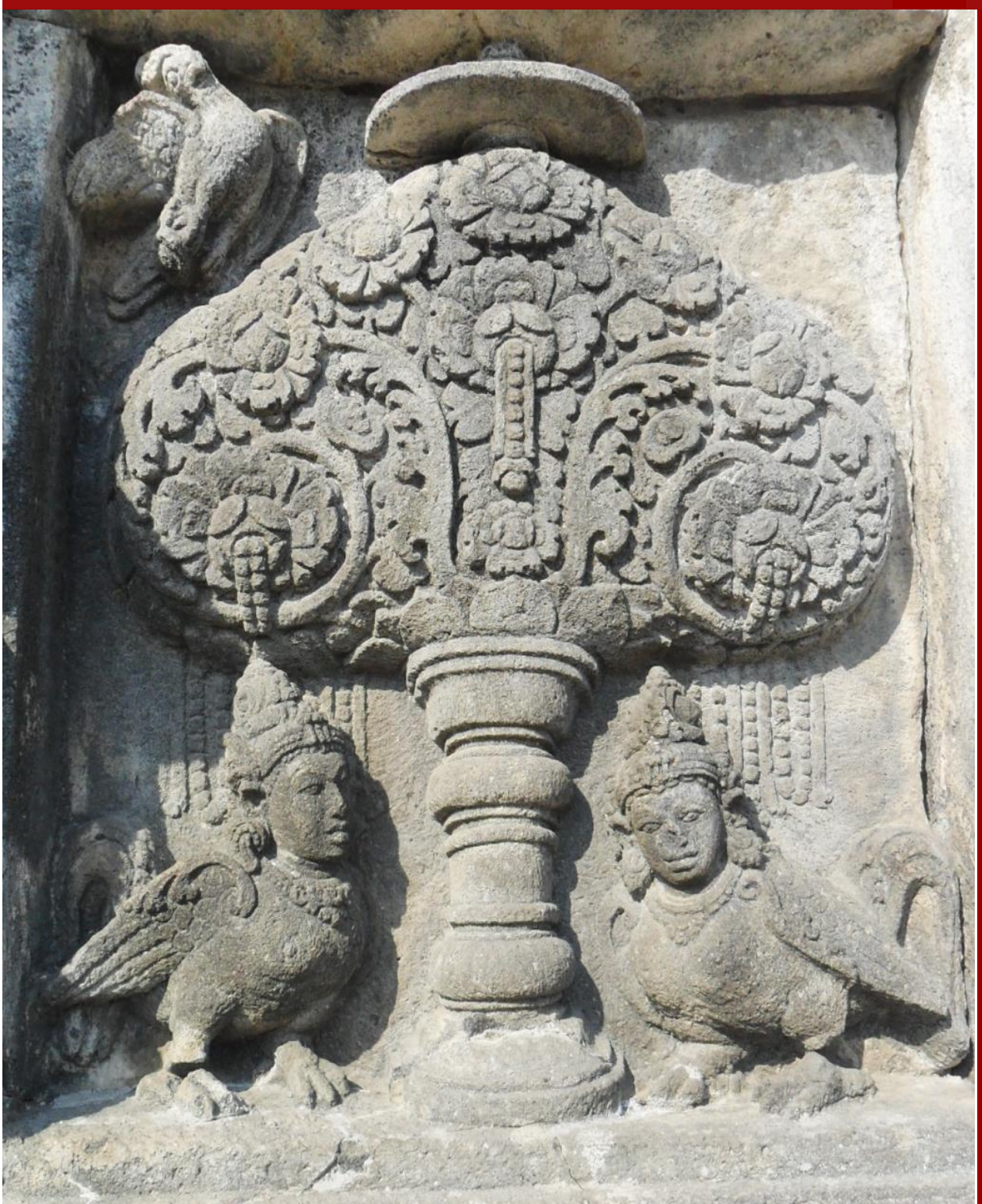

Nilai Budaya Masjid Jami' Sungai Lumpur Kelurahan II Ulu Palembang Sebagai Sumber Pembelajaran Sejarah

Maya Susanti, Muhamad Idris, Aan Suriadi

Analisis Konsep Gender Dalam UndangUndang Simbur Cahaya Sebagai Sumber Pembelajaran Sejarah

Ruli Annisa, Muhamad Idris, Kabib Sholeh

Perbedaan Model Pembelajaran Student Teams Achievement Divisions (STAD) dengan Model Pembelajaran Jigsaw Terhadap Hasil Belajar Siswa Pada Mata Pelajaran Sejarah di SMA Negeri 2 Mesuji

Taufik Sidiki Al-Haq, Nur Ahyani, Ida Suryani

Pengaruh Pemanfaatan Media Youtube Terhadap Hasil Belajar Siswa Mata Pelajaran Sejarah di SMK PGRI 2 Palembang

Riska Anggraini, Nur Ahyani, Ida Suryani

Pengaruh Metode Pembelajaran Daring Terhadap Hasil Belajar Siswa Pada Mata Pelajaran Sejarah di Kelas XI IPA SMA Shailendra Palembang

Christina Leovita Saragih, Nur Ahyani, Aan Suriadi

Pengembangan Media Pembelajaran Digital Bukti-bukti Bangunan Masjid Kuno di Palembang Berbasis Android

Varokah Widiyanti, Eva Dina Chairunisa, Ahmad Zamhari

Hubungan Jawa-Melayu Dalam Dunia Arsitektur Melayu Sumatera Selatan

Reyvaldi Uyun, Muhamad Idris, Ahmad Zamhari

Kondisi Politik Orde Baru di Gorontalo Tahun 1968-1998

Ferrari Yuliawati S, Suryo Ediyono

\author{
JURNAL SEJARAH DAN \\ PEMBELAJARAN SEJARAH
}

Program Studi Pendidikan Sejarah Jurusan Pendidikan IPS

Fakultas Keguruan dan IImu Pendidikan Universitas Persatuan Guru Republik Indonesia Palembang

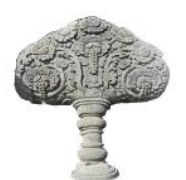

Minat Siswa Terhadap Sejarah dan Budaya Palembang di SMA Negeri 15 Palembang

Febbi Astuti, Muhamad Idris, Kabib Sholeh 


\section{Kalpataru}

Jurnal Sejarah dan Pembelajaran Sejarah

Volume 7, Nomor 1, Juli 2021

\section{Chief Editor}

Drs. Sukardi, M.Pd.

\section{Editor}

Dr. Muhamad Idris, M.Pd.

Eva Dina Chairunisa, M.Pd.

Jeki Sepriady, S.Pd.

\section{Reviewer}

Dr. Tahrun, M.Pd.

Drs. Supriyanto, M.Hum.

Dra. Retno Purwati, M.Hum.

Dr. Nor Huda Ali, M.Ag., M.A.

Dr. Budi Agung Sudarman, S.S., M.Pd.

Dr. Purmansyah, M.A.
(Universitas PGRI Palembang)

(Universitas Sriwijaya Palembang)

(Balai Arkeologi Sumatera Selatan)

(Masyarakat Sejarawan Indonesia Sumsel)

(Balai Bahasa Provinsi Sumatera Selatan)

(Universitas Muhammadiyah Palembang)

\footnotetext{
Alamat Redaksi

Program Studi Pendidikan Sejarah

Fakultas Keguruan dan IImu Pendidikan Universitas PGRI Palembang

Telp. 0711-510043

Email: jurnalkalpatarusejarah@gmail.com

Website: https://jurnal.univpgri-palembang.ac.id/index.php/Kalpa
} 


\section{Kalpataru}

JURNAL SEJARAH DAN

PEMBELAJARAN SEJARAH

Terbit dua kali setahun pada Juli dan Desember

Diterbitkan oleh:

Program Studi Pendidikan Sejarah Jurusan Pendidikan IPS

Fakultas Keguruan

dan IImu Pendidikan

Universitas PGRI Palembang

\section{DAFTAR ISI}

Nilai Budaya Masjid Jami' Sungai Lumpur Kelurahan II Ulu Palembang Sebagai Sumber Pembelajaran Sejarah Maya Susanti, Muhamad Idris, Aan Suriadi...

Analisis Konsep Gender Dalam Undang-Undang Simbur Cahaya Sebagai Sumber Pembelajaran Sejarah Ruli Annisa, Muhamad Idris, Kabib Sholeh ..... 10-18

Perbedaan Model Pembelajaran Student Teams Achievement Divisions (STAD) dengan Model Pembelajaran Jigsaw Terhadap Hasil Belajar Siswa Pada Mata Pelajaran Sejarah di SMA Negeri 2 Mesuji Taufik Sidiki Al-Haq, Nur Ahyani, Ida Suryani. 19-27

Pengaruh Pemanfaatan Media Youtube Terhadap Hasil Belajar Siswa Mata Pelajaran Sejarah di SMK PGRI 2 Palembang Riska Anggraini, Nur Ahyani, Ida Suryani. 28-36

Pengaruh Metode Pembelajaran Daring Terhadap Hasil Belajar Siswa Pada Mata Pelajaran Sejarah di Kelas XI IPA SMA Shailendra Palembang

Christina Leovita Saragih, Nur Ahyani, Aan Suriadi. $37-42$

Pengembangan Media Pembelajaran Digital Bukti-bukti Bangunan Masjid Kuno di Palembang Berbasis Android Varokah Widiyanti, Eva Dina Chairunisa, Ahmad Zamhari

\section{Gambar Cover:}

Pohon Kalpataru

Candi Prambanan

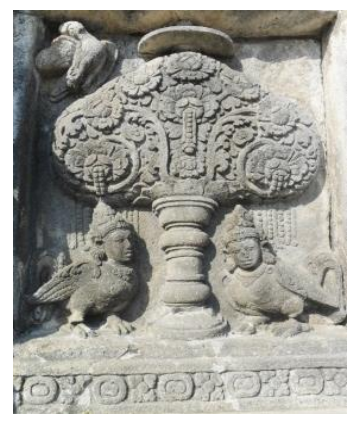

Koleksi: Muhamad Idris
Hubungan Jawa-Melayu Dalam Dunia Arsitektur Melayu Sumatera Selatan Reyvaldi Uyun, Muhamad Idris, Ahmad Zamhari.

Kondisi Politik Orde Baru di Gorontalo Tahun 19681998

Ferrari Yuliawati S, Suryo Ediyono.

Nilai-nilai Sejarah dan Budaya Ikonografi Megalith di Lahat Sebagai Sumber Pembelajaran Sejarah Nasional Jainal Arifin, Sukardi, Dina Sri Nindiati.

Minat Siswa Terhadap Sejarah dan Budaya Palembang di SMA Negeri 15 Palembang Febbi Astuti, Muhamad Idris, Kabib Sholeh. 77-82 


\title{
ANALISIS KONSEP GENDER DALAM UNDANG-UNDANG SIMBUR CAHAYA SEBAGAI SUMBER PEMBELAJARAN SEJARAH
}

\author{
Ruli Annisa \\ Guru di SMA Negeri 15 Palembang \\ Email: rullyannisaa@gmail.com \\ Muhamad idris \\ Dosen Program Studi Pendidikan Sejarah FKIP Universitas PGRI Palembang \\ Email: idrismuhamad1970@gmail.com \\ Kabib Sholeh \\ Dosen Program Studi Pendidikan Sejarah FKIP Universitas PGRI Palembang \\ Email: habibsholeh978@gmail.com
}

\begin{abstract}
ABSTRAK
Undang-undang Simbur Cahaya merupakan hukum adat yang berkalu di wilayah Uluan Sumatera Selatan pada abad ke-17 Masehi pada masa Kesultanan Palembang Darusalam sampai zaman Kolonial pada akhir abad ke-20 Masehi yang digagaskan oleh Ratu Sinuhun terdiri dari 5 BAB yang salah satunya mengatur tentang bujang gadis dan hukum perkawinan. Masalah pada penelitian ini adalah bagaimana hasil analisis konsep gender yang terdapat dalam Undang-undang Simbur Cahaya sehingga dapat dijadikan sumber pembelajaran sejarah. Tujuan penelitian ini untuk mengetahui dan menganalisis konsep gender yang terdapat dalam Undang-undang Simbur Cahaya. Penelitian ini menggunakan metode deskriptif kualitatif dengan teknik pengumpulan data yang digunakan adalah observasi, dokumentasi, wawancara mendalam. Teknik analisis data dilakukan dengan tiga tahap yaitu reduksi data, penyajian data dan penarikan kesimpulan. Hasil penelitian dan pembahasan menunjukkan bahwa konsep gender yang terdapat Naskah Undang-undang Simbur Cahaya memiliki hubungan dengan hukum Islam yang berdasarkan Al-Qur'an dan Hadist sehingga dapat dimanfaatkan sebagai sumber pembelajaran sejarah di sekolah.
\end{abstract}

Kata Kunci: Gender, Simbur Cahaya, Pembelajaran.

\section{A. PENDAHULUAN}

Gender adalah konsep yang digunakan untuk mengidentifikasi perbedaan antara lakilaki dan perempuan berdasarkan pengaruh sosial dan budaya. Dalam pengertian gender adalah suatu bentuk konstruksi sosial, bukan hal yang wajar, dalam hal ini gender harus dibedakan dengan gender jenis kelamin tertentu. Pada saat yang sama, konsep gender merupakan ciri yang melekat pada laki-laki dan perempuan dan dikonstruksi secara sosial dan budaya, misalnya seperti yang kita ketahui bersama, perempuan itu lembut dan cantik. Gender mengacu pada perbedaan perilaku yang dikonstruksi secara sosial antara laki-laki dan perempuan (perbedaan perilaku), yaitu bukan perbedaan alami atau perbedaan yang ditentukan oleh Tuhan, tetapi perbedaan yang disebabkan oleh manusia (pria dan wanita) melalui proses sosial dan budaya yang panjang (Surah, 2013:377).

Sejarah perbedaan gender antara lakilaki dan perempuan merupakan proses yang sangat panjang, banyak alasan pembentukannya, seperti kondisi budaya tertentu, kondisi agama dan kondisi kenegaraan. Perbedaan gender sering kali dianggap sebagai peraturan Tuhan, dengan karakteristik biologis yang alami atau tampaknya tidak dapat diubah. Secara istilah gender dapat diartikan sebagai ekspektasi budaya laki-laki dan perempuan gender 


\section{Kalpataru, Volume 7, Nomor 1, Juli 2021 (10-18)}

dipandang sebagai konsep budaya yang digunakan untuk membedakan peran, perilaku, karakteristik psikologis dan emosional antara laki-laki dan perempuan yang berkembang di masyarakat. Diketahui bahwa gender merupakan karakteristik yang digunakan sebagai dasar untuk mengidentifikasi perbedaan antara laki-laki dan perempuan dari segi kondisi sosial budaya, nilai dan perilaku, spiritual dan emosional, serta faktor non-biologis lainnya. Sehingga selalu ada pembeda antara laki-laki dan perempuan yang tidak bisa disatukan (Rokhmansyah, 2016:1-3).

Agama Islam masuk ke Palembang pada abad ke-7 Masehi dan mulai berkembang pada abad ke-15 Masehi. Masuknya agama Islam di Palembang memiliki hubungan dengan Kerajaan Sriwijaya karena adanya bukti hubungan kerjasama perdagangan antara para pedagang Sriwijaya dan pedagang asing mulai dari Cina, India dan Arab. Bukti hubungan dagang Sriwijaya dan pedagang Arab terlihat dari berita-berita Arab yang menyatakan bahwa adanya hubungan perdagangan pada saat itu (Sholeh, 2015:45).

Palembang merupakan salah satu daerah di Indonesia yang memiliki kekayaan berupa naskah kuno. Naskah kuno biasanya berisi tentang ketuhanan, ajaran budi pekerti, sejarah, cerita rakyat, dongeng, legenda, teknologi tradisional, mantra, silsilah, jimat, syair, politik, pemerintahan, undang-undang, hukum, adat, pengobatan tradisional, hikayat dan lain sebagainya. Salah satunya adalah Naskah Simbur Cahaya yang merupakan salah satu hukum tertulis yang berupa undangundang yang mengatur masyarakat Palembang dalam bermasyarakat, ada banyak sekali aturan yang terdapat dalam Naskah Simbur Cahaya salah satunya mengatur hubungan antara lakilaki dan perempuan dalam bersikap dan mengatur hukum perkawinan yang harus ditaati masyarakat dahulu (Latiar, 2018:68).

Naskah Undang-undang Simbur Cahaya merupakan sebuah kitab undang-undang yang memadukan antara hukum adat dan ajaran Islam. Kitab Simbur Cahaya disusun oleh Ratu Sinuhun yang merupakan istri penguasa Palembang, Pangeran Sido Ing Kenayan (16301642 Masehi). Hukum Simbur Cahaya merupakan hukum adat yang berkembang dan berlaku antar warga yang berada di daerah Ulu Sumatera Selatan. Keseluruhan isi Undangundang Simbur Cahaya sebuah aturan yang mengatur perilaku masyarakat baik secara individu atau bersifat umum. Dari berbagai aturan yang terdapat di dalam Undang-undang Simbur Cahaya pada penelitian ini lebih memfokuskan pada hukum perkawinan, aturan bujang dan gadis. Hukum gender yang diatur dalam Undang-undang Simbur Cahaya yang harus ditaati masyarakat karena mengatur hubungan antara laki-laki dan perempuan dalam bermasyarakat serta mengatur hukum perkawinan yang harus ditaati masyarakat akan ada sanksi bagi siapa pun yang melanggarnya. Aturan yang terdapat dalam Undang-undang Simbur Cahaya ini dapat dijadikan sumber pengetahuan siswa mengenai aturan yang pernah berlaku di Palembang yang sudah ada sejak lama (Wirajaya, 2018:34-35).

Menurut AM Hens dalam (Pranata, 2018:6-7) Undang-undang Simbur Cahaya sudah mengatur hubungan bergaul antara bujang gadis dalam bermasyarakat seperti yang terlihat pada Bab 1 tentang aturan bujang gadis dan kawin pasal 18 yang berbunyi "jika laki-laki senggol tangan gadis atau rangda (nare gawe namanja), ia kena denda 2 ringgit jika perempuan itu mengaduh dan 1 ringgit pulang pada perempuan itu dan 1 ringgit lagi jatuh pada kepala dusun" yang dimaksud pada pasal ini mengandung nilai moral etika dalam bergaul antara laki-laki dan perempuan dilarang bersentuhan apabila bukan muhrim. Dilihat dari aturannya memiliki kaitan dengan hukum Islam yang mengatur hubungan laki-laki dan perempuan yang belum muhrim atau belum menikah.

Undang-undang Simbur Cahaya merupakan sistem aturan adat yang populer di kalangan masyarakat Palembang sangat erat kaitannya dengan ajaran moral. Undangundang Simbur Cahaya ini diterapkan pada masa Kerajan Palembang, Kesultanan Palembang sampai masa Keresidenan Palembang akan tetapi Undang-undang Simbur Cahaya ini mengalami perubahan pada saat Palembang dikuasai oleh Kolonial Belanda. Nilai-nilai dan ajaran moral yang terdapat dalam 
Undang-Undang Simbur Cahaya inilah yang dapat dijadikan sebagai sumber pembelajaran sejarah di sekolah (Amanah, 2020:28-29).

Peranan gender dalam undang-undang tentunya sudah banyak diatur sehingga adanya batasan antara laki-laki dan perempuan. Terutama perempuan yang memiliki hak yang harus dilindungi dalam undang-undang. Hukum dan peraturan perundang-undangan Indonesia mengakui tentang adanya prinsip persamaan hak antara laki-laki dan perempuan. Syarat bagi pria dan wanita untuk menikmati status kesetaraan dan kondisi yang sama untuk mewujudkan hak asasi manusia dan potensi pembangunannya secara penuh disemua bidang kehidupan (Puspawati, 2013:5).

Undang-undang Simbur Cahaya merupakan hukum adat yang berlaku di Sumatera Selatan, sejarah kelokalan ini jarang sekali diketahui masyarakat dan dipelajari di sekolah sehingga penulis membuat penelitian ini agar dapat melestarikan sejarah kelokalan yang ada.

\section{B. METODE PENELITIAN}

Penelitian ini menggunakan metode penelitian deskriptif kualitatif, yang menggunakan cara mengumpulkan sumbersumber secara sistematis dan menggunakan sumber data secara mendalam. Objek penelitian kualitatif adalah semua bidang/aspek kehidupan manusia, yaitu manusia dan segala sesuatu yang dipengaruhi oleh manusia. Objek penelitian kualitatif diungkap sebagaimana keadaannya yang berkenaan dengan aspek kehidupan manusia dalam bidang ekonomi, budaya, hukum. Administrasi, agama dan sebagainya (Fitrah, 2017:45).

\section{Teknik Pengumpulan Data}

Teknik pengumpulan data merupakan langkah paling strategis dalam penelitian, karena tujuan utama penelitian adalah untuk memperoleh data. Pengumpulan data berdasarkan tekniknya yaitu melalui: observasi, dokumentasi, wawancara dan studi pustaka.

\section{Observasi}

Observasi adalah teknik untuk mengekstrak data sumber daya berupa tempat, kegiatan, benda atau catatan gambar. Obsevasi ini meliputi tahapan, pengamatan tentang masalah yang diteliti. Setelah itu tentukan aspek yang mana menjadi pusat perhatian, batasan objek dan catatan. Selama pengamatan, perlu peka terhadap mata pengetahuan telinga dan target observasi peneliti tidak berdampak pada penelitian aktivitas/peristiwa/objek yang diamati. Pada penelitian ini akan dilakukan observasi terkait dengan sumber pembelajaran di sekolah (Nugrahani, 2014:132-133).

\section{Dokumentasi}

Dokumen merupakan sumber data yang digunakan untuk melengkapi data penelitian, baik berupa sumber tertulis, film, gambar, dan karya-karya monumental, yang semuanya itu memberikan informasi bagi proses penelitian. Dokumentasi adalah proses pembuktian yang didasarkan atas jenis sumber apapun, yaitu dalam bentuk tulisan, lisan, gambaran, arkeologis (Sugiyono, 2011:80-82).

\section{Wawancara}

Teknik wawancara adalah teknik data melalui percakapan dengan tujuan tertentu, dari dua atau lebih kelompok dalam penelitian kualitatif biasanya menjadi sumber data primer adalah orang informan. Oleh karena itu, wawancara mendalam adalah teknik penambangan data utama yang memungkinkan peneliti mendapatkan data sebanyak mungkin, lengkap dan mendalam. Wawancara mendalam pada penelitian ini dengan pakar budaya, dosen sejarah dan guru mata pelajaran sejarah di sekola (Nugrahani, 2014:124-125).

\section{Studi Pustaka}

Dalam penelitian kualitatif juga menggunakan tata cara pengumpulan data melalui studi pustaka dan studi lapangan. Studi pustaka berbeda dengan tinjaun pustaka, studi pustaka dilakukan dengan cara mengkaji sumber tertulis seperti dokumen, laporan tahunan, peraturan perundangan dan diploman/sertifikat. Pengumpulan data melalui studi lapangan terkait dengan situasi alamiah. Pengumpulan data sebaiknya dilakukan secara bertahap dan harus mendapatkan informasi 
sebanyak mungkin agar mempermudah jalannya penelitian (Nilamsari, 2014:179).

\section{HASIL DAN PEMBAHASAN}

\section{Sejarah Undang-undang Simbur Cahaya}

Simbur Cahaya memiliki arti percikan cahaya. Undang-udang Simbur Cahaya merupakan suatu hukum adat yang terpakai di daerah Ulu sejak abad ke-17 Masehi. Naskah asli Undang-undang Simbur Cahaya ditulis dengan aksara Arab yang dibuat oleh Ratu Sinuhun yang merupakan istri dari penguasa Palembang yaitu Raja Side Ing Kenayan (16291636). Undang-undng Simbur Cahaya dibuat dengan campur tangan pemimpin masyarakat pada saat itu, seperti ulama, pejabat kerajaan dan pangeran Kesultanan Palembang Darusalam. Undang-undang Simbur Cahaya terdiri dari 5 bab yaitu: 1) Bab I tentang Aturan Bujang Gadis Kawin (32 pasal); 2) Bab II tentang Aturan Marga (29 pasal); 3) Bab III tentang Aturan Dusun dan Berladang (34 pasal); 4) Bab IV tentang Aturan Kaum (19 pasal); 5) Bab V tentang Adat Perhukuman (58 pasal). Hukum adat ini dibuat karena adanya perkara-perkara berat yang sering terjadi seperti adanya pemberontakan dan pembunuhan yang tidak dapat diselesaikan oleh masyarakat sendiri sehingga harus dibawa ke ibu kota dan diselesaikan oleh pihak kerajaan. Sanksi yang sering dikenakan kepada para pelaku kejahatan biasanya dibawa oleh pihak kerajaan ke Bukit Seguntang untuk disumpah. Sanksi lainnya yaitu hukum Kapanjing dengan cara diasingkan ke daerah tertentu yang jauh dari daerah asalnya agar pelaku tidak bisa atau sulit berhubungan dengan kerabatnya (Budenani, 1961:2-3).

Undang-undang Simbur Cahaya ditulis ke dalam hukum adat yang diterapkan pada daerah pedalaman pedesaan pada masa Kesultanan Palembang dan mengatur semua urusan masyarakat sehari-hari. Undang-undang Simbur Cahaya terus dipakai sampai pada masa penjajahan Belanda, akan tetapi sifatnya sudah berubah. Undang-undang Simbur Cahaya mengalami perubahan pada April 1933 dan dicetak pertamakali dengan menggunakan huruf Arab yang disebut dengan huruf Arab Melayu. Pada percetakan pertama ini secara resmi Undang-undang Simbur Cahaya mengalami perubahan. Disebabkan suasana yang sudah berbeda, perubahan itu juga disebabkan adanya keputusan kepala negeri (kepala-kepala marga) yang berhimpun di Palembang pada tanggal 2-6 September 1927 yang diketahui oleh Residen Palembang (Budenani, 1961:3).

Secara umum hukum yang diberikan kepada pelaku biasanya dalam bentuk denda. Besar atau kecil ukuran dendanya tergantung pada kesalahan yang dilakukan para pelaku sesuai dengan ketentuan dalam Undangundang Simbur Cahaya. Sanksi yang terdalam dalam Undang-undang Simbur Cahaya dibuat untuk memberikah efek jera bagi para pelanggarnya. Selain itu, hukuman lainnya yang biasanya didapatkan adalah sanksi sosial yang terdapat dalam lingkungann masyarakat tersebut. Melihat sanksi yang berlaku sehingga membuat masyarakat segan melanggar peraturan yang terdapat dalam Undang-undang Simbur Cahaya. Masyarakat tradisional merupakan masyarakat yang selalu menjunjung tinggi adat istiadat yang berlaku. Dengan demikian, Undang-undang Simbur Cahaya merupakan peraturan yang sangat penting bagi masyarakat Uluan untuk mengatur kehidupannya dalam bermasyarakat. Undangundang Simbur Cahaya dipakai terus walaupun penjajahan telah menaklukan Kesultanan Palembang pada tahun 1824, akan tetapi sifatnya berubah. Awalnya Undang-undang Simbur Cahya ini undang-undang dasar, tetapi oleh penjajah diubah dijadikan hukum adat. Setelah mengalami perubahan maka dijadikan undang-undang adat (Budenani, 1961:4).

\section{Gender Laki-laki dan Perempuan dalam Undang-undang Simbur Cahaya}

Perbedaan antara pria dan wanita seringkali menimbulkan masalah, pasalnya sebagian besar masyarakat memahami konsep gender, yaitu sebagai konsep yang hanya terkait dengannya masalah kepribadian wanita sendiri. Meskipun gender berbeda dengan jenis kelamin, gender tidak hanya sekedar dibicarakan khusus wanita atau khusus pria, ini bukan konsep yang berbeda biologi yang dimiliki keduanya. Gender adalah perbedaan antara 
peran laki-laki dan perempuan dibentuk oleh komunitas atau kelompok komunitas yang memiliki budaya, latar belakang dan struktur sosial yang berbeda wilayah, ras, negara bagian, dan agama. Oleh karena itu, perbedaan tingkah laku dan karakteristik peran laki-laki dan perempuan yang digunakan di suatu tempat/budaya belum tentu sama atau yang terapkan di tempat lain. Dalam Undang-undang Simbur Cahaya aturan mengenai laki-laki dirancang untuk memberikan pelajaran dan efek jera bagi yang melanggar baik itu dalam bermasyarakat maupun hukum perkawinan (Yuda, 2018:40).

Laki-laki dan perempuan memiliki peran masing-masing dalam lingkungan bermasyarakat. Disetiap tempat memiliki aturan yang berlaku dan harus ditaati bagi setiap orang yang ada ditempat tersebut begitu juga dengan Undang-undang Simbur Cahaya yang berlaku pada masyakat Uluan Sumatera Selatan. Pada pasal-pasal Undang-undang Simbur Cahaya yang mengatur kehidupan laki-laki pada saat berinteraksi dengan perempuan dan masyarakat lainnya. Seperti pasal 1-3 pada bab 1 yang mengatur hukum perkawinan dan uang yang harus diberikan laki-laki kepada perempuan yang akan dinikahinya semua sudah diatur pada pasal tersebut. Selain hukum perkawinann ada banyak sekali pasal yang mengatur kehidupan bujang gadis daerah Uluan pada saat itu.

Undang-undang Simbur Cahaya yang dirancang oleh Ratu Sinuhun yang berarti perempuan memegang peranan penting dalam masyarakat, secara langsung atau tidak langsung pada saat itu. Ratu Sinuhun diperkirakan lahir di Palembang pada sekitar akhir abad ke-16, dan wafat pada tahun $1642 \mathrm{M}$. Tujuan Ratu Sinuhun menyusun Undangundang Simbur Cahaya untuk melindungi dan meninggikan nilai-nilai perempuan pada saat itu agar tidak direndahkan dan diperlakukan seenaknya saja. Undang-undang Simbur Cahaya merupakan kitab yang terkenal dengan kekhasannya dalam memperjuangkan hak-hak perempuan, serta memberikan perlindungan kepada para wanita. Aturan yang bersumber dari Undang-undang Simbur Cahaya masih terlihat hingga sekarang. Ratu Sinuhun membuat aturan tersebut untuk menjaga dan melindungi perempuan karena sejarahnya perempuan dianggap makhluk yang lemah dan ada banyak sekali kasus laki-laki yang sering melecehkah perempuan dan juga pada zaman Kesultanan Palembang banyak sekali praktik perbudakan dan penjualan perempuan, oleh karena itulah Ratu Sinuhun membuat aturan Undang-undang Simbur Cahaya untuk melindungi harkat dan martabat perempuan. Undang-undang Simbur Cahaya telah memberi penjelas status dan kedudukan perempuan dalam masyarakat beserta memperjuangkan hak-haknya (Yuda, 2018:34).

Perempuan adalah makhluk yang lemah dan sudah menjadi sebuah keharusan bagi lakilaki untuk menjaga perempuan di lingkungan sekitarnya baik itu ibunya, adik perempuan, istri dan lain-lain. Dalam pasal-pasal yang menyangkut tentang perempuan yang sudah di jelaskan di Undang-undang Simbur Cahaya isinya banyak bertujuan untuk melindungi dan menjaga perempuan. Sanksi dan denda bagi yang mengganggu dan melecehkan perempuan akan dihukum sesuai dengan kesalahan yang dilanggarnya. Seperti contoh pada pasal 21 bab 1 yang intinya jika ada laki-laki yang menyentuh perempuan yang bukan mahramnya maka ia akan didenda sebesar 12 ringgit. Pada pasal ini menunjukkan bahwa peraturan Undang-undang Simbur Cahaya sangat tepat diterapkan pada masyarakat. Selain itu ada banyak pasal yang mengatur kehidupan perempuan dalam bermasyarakat mulai dari perkawinan yang dimana laki-laki harus memberi mahar kepada perempuan kemudian perempuan harus melalui masa idah jika ditinggal suaminya semua ada pada setiap pasal di Undang-undang Simbur Cahaya.

\section{Relevansi Konsep Gender dalam Undang- undang Simbur Cahaya dan Syariat Islam \\ Gender dalam perspektif Islam} merupakan sebuah konsep perbedaan antara laki-laki dan perempuan yang meliputi hak, kewajiban, nilai dan tingkah laku dan berbagai persoalan yang lebih didominasi oleh perempuan yang menyangkut keterlibatan wanita dalam berbagai bidang menurut AlQur'an dan Hadist. Peranan gender dalam 
perspektif Islam meliputi, peranan wanita dalam keluarga sebagai seorang ibu, istri, dan sebagai anak, peranan wanita dalam kehidupan sosial serta peranan wanita dan keterlibatannya dalam bidang agama, profesi dan politik. Al-Qur'an sendiri telah menjelaskan status pria dan wanita memiliki status yang sama di mata Allah, dan mereka semua bisa menjadi makhluk ideal tanpa diskriminasi gender, meski dalam beberapa kasus akan ada interpretasi yang berbeda soal posisi laki-laki dan perempuan. Hukum Simbur Cahaya juga memberikan penjelasan status perempuan dalam masyarakat berjuang untuk haknya. Ada banyak sekali ayat dalam Al-Qur'an yang berkaitan tentang gender. Dalam QS. AlHujurat:13 yang menjelaskan tentang ikatan persaudaraan antara laki-laki dan perempuan.

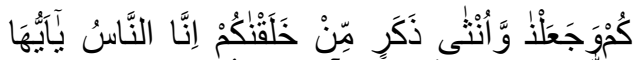

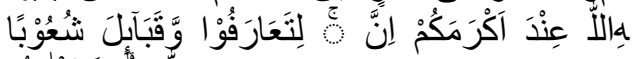

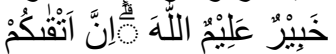

"Hai manusia, sesungguhnya kami menciptakan kamu dari seorang laki-laki dan seorang perempuan dan menjadikan kamu berbangsa-bangsa dan bersukusuku supaya kamu saling kenalmengenal. Sesungguhnya orang yang paling mulia di antara kamu disisi Allah ialah orang yang paling taqwa di antara kamu. Sesungguhnya Allah Maha mengetahui lagi Maha Mengenal (QS. AlHujurat:13).
\end{abstract}

Dalam ayat tersebut Allah menyampaikan bahwa laki-laki dan perempuan dari berbagai macam suku, ras, bangsa, dan budaya adalah saudara dan Islam tidak membedakan antara hak dan kewajiban yang ada pada diri manusia hak dan kewajiban itu dinilai sama dimata Allah (Zahriyanti, 2015:90).

Perbedaan yang tampak antara laki-laki dan perempuan apabila dilihat dari nilai dan tingkah laku jelas sangat berbeda. Ayat AlQur'an yang terkenal berbicara tenang asal terciptanya manusia adalah firman Allah dalam QS. An-Nisa.

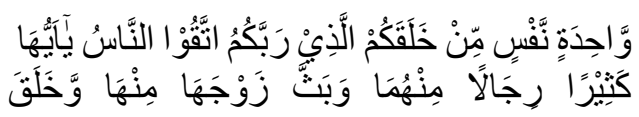

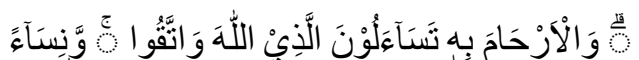

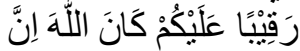

"Hai sekalian manusia, bertaqwalah kepada Tuhanmu, yang telah menciptakan kamu dari diri (nafs) yang satu, dan darinya Allah menciptakan pasangannya dan keduanya Allah mengembangbiakkan laki-laki dan perempuan yang banyak.....". (Q.S. AnNisa:1).

Maksud ayat di atas adalah bahwa Allah menciptakan manusia dari Nafs yang menurut ulama tafsir adalah Adam dan pasangannya yaitu istrinya Siti Hawa lalu kemudian Allah menciptakan mereka berpasangan dan keduanya memberikan keturunan adam laki-laki dan perempuan (Zahriyanti, 2015:91).

Dalam Undang-undang Simbur Cahaya banyak sekali pasal yang mengatur bujang dan gadis agar tidak bersentuhan tangan, tidak berduaan yang berarti melarang mereka untuk mendekati zinah seperti yang terlihat pada Bab I Pasal 18 yang berbunyi "Jika laki-laki senggol tangan gadis atau rangda naro gawe namanya, ia kena denda 2 ringgit, jika perempuan itu mengadu dan 1 ringgit pulang pada perempuan itu dan 1 ringgit jatuh kepada kepala dusun serta punggawanya." Pasal ini berkaitan dengan ajaran Islam yang teradapat pada hadist yang berbunyi "Dari Ubadah ibn Ash-Shamit ia berkata: Rasulullah SAW bersabda: Ambillah dari diriku, ambillah dari diriku, sesungguhnya Allah telah memberikan jalan keluar (hukuman) bagi mereka (pezina). Jejaka dan gadis hukumannya dera 100 kali dan pengasingan selama satu tahun, sedangkan duda dan janda hukumannya dera 100 kali dan rajam." (diriwayatkan oleh jama'ah kecuali Bukhori dan Nasa'i). Dari hadist yang ada di atas Undangundang Simbur Cahaya merupahan hukum adat yang memiliki kaitan dengan hukum Islam (Huda, 2015:377).

Dari berbagai ayat Al-Qur'an dan hadist yang ada ternyata memiliki hubungan dengan pasal yang terdapat dalam Undang-undang Simbur Cahaya sehingga kaitan ini memperkuat adanya hubungan hukum Islam dan hukum adat pada Undang-undang Simbur Cahaya. Selain isi yang terdapat pada pasal Undang-undang 
Simbur Cahaya yang memiliki hubungan dengan hukum Islam masa berlakunya Undangundang Simbur Cahaya pada masa Kesultanan Palembang yang berarti hukum Islam ada hubungan dan campur tangan dengan hukum adat masyarakat Uluan yaitu Undang-undang Simbur Cahaya.

\section{Keberpihakan Gender dalam Undang- undang Simbur Cahaya}

Undang-undang Simbur Cahaya yang terdiri 5 bab yang mengatur hubungan masyarakat uluan pada abad ke-17 Masehi di dalamnya terdapat aturan yang mengatur hubungan antara laki-laki dan perempuan. Dilihat dari pasal yang ada dari setiap bab, pada Bab I yang lebih banyak mengatur tentang hubungan gender dalam masyarakat karena terdapat 29 pasal pada Bab 2 terdapat 1 pasal dan pada Bab $\mathrm{V}$ terdapat masing masing 4 pasal. Jika dijumlahkan terdapat 36 pasal yang masing-masing mengatur hubungan antara lakilaki dan perempuan dalam Undang-undang Simbur Cahaya (Budenani, 1961:1).

Berikut adalah tabel pembagian pasal dan aturan laki-laki dan perempuan pada Undang-undang Simbur Cahaya:

Tabel 4.4

Pasal Tentang Gender dalam Undangundang Simbur Cahaya

\begin{tabular}{|c|l|l|}
\hline No & \multicolumn{1}{|c|}{ Gender Laki-laki } & \multicolumn{1}{c|}{$\begin{array}{c}\text { Gender } \\
\text { Perempuan }\end{array}$} \\
\hline \multirow{6}{*}{1} & Bab I Aturan Bujang & Bab I Aturan Bujang \\
& Gadis dan Kawin & Gadis dan Kawin \\
& (P1, P2, P3, P4, P5, & (P1, P6, P7, P8, P9, \\
& P6, P7, P8, P9, & P10, P11, P12, P13, \\
& P12, P13, P14, & P17, P18, P19, P20, \\
& P15, P16, P17, & P21, P22, P23, P24, \\
& P18, P19, P20, & P25, P26, P28, P29, \\
& P21, P22, P23, & P30, P31, P32) \\
& P24, P25, P26 P29, & \\
& P30, P31, P32) & \\
\hline \multirow{2}{*}{2} & Bab Il Aturan Marga & Bab II Aturan Marga \\
& (P28) & (P28, P29) \\
\hline \multirow{5}{*}{3} & Bab V Adat & Bab V Adat \\
& Perhukuman & Perhukuman \\
& (P19, P36, P41, & (P19, P36, P41, \\
& P52 P53, P55) & P52, P53, P54) \\
\hline \multirow{2}{*}{} & 36 Pasal & 32 Pasal \\
\hline
\end{tabular}

Pembagian hak dan kewajiban antara laki-laki dan perempuan pada setiap pasal Undang-undang Simbur Cahaya pada umumnya sama. Perempuan dan laki-laki pada dasarnya memiliki peran dan kedudukan penting dalam bermasyarakat. Secara keseluruhan perlakuan hukum laki-laki dan perempuan dalam Undang-undang Simbur Cahaya sama dan tidak ada aturan yang membedakan antara laki-laki dan perempuan. Hal tersebut ada pada peraturan tentang pencurian, perkelahian, persaksian dan semua aturannya berlaku bagi seluruh masyarakat baik laki-laki maupun perempuan (Wulandari, 2020:50).

Gender adalah sebuah konsep yang menggambarkan hubungan antara pria dan wanita. Wanita dianggap berbeda menurut konstruksi sosial dan budaya, termasuk beda peran, fungsi dan tanggung jawab. Gender adalah pembedaan peran dan fungsi tanggung jawab dengan wanita dan pria lahir dari arsitektur budaya sosial dapat didasarkan pada ikuti perkembangan zaman. Pembagian tugas antara laki-laki dan perempuan memang sudah ada sejak dahulunya. Akan tetapi, perempuan pada masa sebelumnya ada keterbatasan melakukan kegiatannya baik itu dalam bentuk pendidikan ataupun pekerjaan. Diera sekarang laki-laki dan perempuan memiliki hak yang sama dalam melakukan aktivitas di dalam maupun di luar rumah. Pada masa Kesultanan Palembang terdapat peraturan adat yang berfungsi untuk melindungi perempuan dan membuat perempuan memiliki hak yang sama dengan laki-laki. Oleh karena itu diciptakannya Undang-undang Simbur Cahaya agar dapat membuat kehidupan masyarakat menjadi lebih aman dan tentram (Andika, 2019:138).

\section{SIMPULAN}

Hukum Simbur Cahaya adalah kitab hukum adat yang menggabungkan hukum adat yang berkembang secara lisan di Sumatera Selatan dan dalam ajaran Islam. Buku ini terbagi dalam 5 bab yang merupakan bagian dari lembaga hukum dan adat di Sumatera Selatan, khususnya bab tentang kesetaraan gender antara laki-laki dan perempuan. 
Simbur Cahaya merupakan sistem peradatan yang diterapkan di Sumatera Selatan, inilah tradisi tertua dan primitif yang dipraktikkan sejak ratusan tahun lalu daerah. Tradisi ini memasukkan nilai-nilai kehidupan dalam bentuk tertulis Undang-undang Simbur Cahaya dan isinya disimpan dalam perjanjian, kenangan dan kebiasaan orang. Nilai kesopanan, komunitas Sumatera Selatan bertahan dan mengatasi berbagai masalah kehidupan sosial bergaul dengan lingkungan alam dan dengan manusia. Rasa persatuan inilah nilai utama Simbur Cahaya yang tidak hanya termuat dalam tulisan, tetapi juga tercermin dalam keseharian masyarakat.

Menurut peraturan Undang-undang Simbur Cahaya, hukuman denda bergantung pada skala kesalahan pelaku pada saat itu. Berbagai bentuk hukuman biasanya memiliki efek jera bagi pelakunya. Selain itu, hukum yang tidak kalah pentingnya adalah sanksi sosial yang berlaku saat itu. Pada masyarakat adat yang menjaga adat istiadatnya, angka ini menyebar kemana-mana, sehingga masyarakat mempertimbangkan kembali apabila ingin melanggar hukum adat yang berlaku dalam Undang-undang Simbur Cahaya. Oleh karena itu, Undang-undang Simbur Cahaya menjadi tolak ukur yang sangat penting bagi penegakan hukum di wilayah Uluan Palembang.

\section{DAFTAR PUSTAKA}

Amanah, L. D. 2020. "Tradisi Simbur Cahaya di Desa Saranglang Kecamatan Pemulutan Barat Kabupaten Ogan Ilir Sumatera Selatan". dalam Jurnal Loghotu. (28-29).

Andika, M. 2019. "Reinterpretasi Ayat Gender dalam Memahami Relasi Laki-laki dan Perempuan (Sebuah Kajian Kontekstual dalam Penafsiran)". Dalam Jurnal Studi Gender dan Islam. (138).

Budenani. 1961. Undang-undang Simburtjahaya yang Terpakai di Pedalam Palembang. Jakarta: Bagian Bahasa Djawa. Kebudayaan.
Fitrah, M. 2017. Metodelogi Penelitian: Penelitian Kualitatif, Tindakan Kelas \& Studi Kasus. Sukabumi: CV Jejak.

Huda, S. 2015. "Zina dalam Prespektif Hukum Islam dan Kitab Undang-Undang Hukum Pidana". Dalam Jurnal Studia Islamika. (377).

Latiar, H. 2018. "Preservasi Nakah Kuno Sebagai Upaya Pelestarian Budaya Bangsa". Dalam Jurnal Perpustakaan dan Informasi. (68).

Nilamsari, N. 2014. "Memahami Studi Dokumen dalam Penelitian Kualitatif". Dalam Jurnal IImiah IImu Komunikasi. (179).

Nugrahani. 2014. Metodelogi Penelitian Kualitatif. Solo: Cakra Books.

Pranata, O. 2018. "Naskah Simbur Cahaya Sebagai Sumber Pembelajaran Moral Pada Mata Pelajaran Sejarah". Dalam Kalpataru. (6-7).

Puspawati, H. 2013. "Konsep, Teori dan Analisis Gender". Dalam Departemen IImu Keluarga dan Konsumen Fakultas Ekologi Manusia Institut Pertanian. (1).

Rokhmansyah, A. 2016. "Pengantar Gender dan Feminisme: Pemahaman Awal Keritik Sastra Feminisme". Dalam Jurnal Garudhawacana. (1-3).

Sholeh, K. 2015. "Khalifah Dagang Muslim dan Peranan Maritim Kerajaan Sriwijaya di Palembang Pada Abad VII-IX Masehi". Dalam Kalpataru. (45).

Sugiyono. 2011. Metodelogi Penelitian Kuantitatif, Kualitatif dan R\&D. Bandung: Alfabeta.

Surah, S. 2013. Kesetaraan Gender dalam Prespektif Al-Qur'an dan Implikasinya Terhadap Hukum Iskam. Dalam Jurnal Al-Ulum. (377). 
Wirajaya, A. 2018. "Transformasi Palembang Menuju Kota Multikultural: Sebuah Refleksi Terhadap Naskah UndangUndang Simbur Cahaya dan Tuhdah Ar-Raghabin". Dalam Jurnal of Islamicate Multidisciplinary. (34-35).

Wulandari, D. M. 2020. "Undang-undang Simbur Cahaya dalam Mengatur Hukum Perkawinan di Kesultanan Palembang". Dalam Jurnal Antropologi. (190-191).

Yuda, A. 2018. "Transformasi Palembang Menuju Kota Multikultural (Sebuah Refleksi Terhadap Naskah Undangundang Simbur Cahaya Dengan Tuhfah Ar-Raghibin)". Dalam Jurnal Shahih.

Zahriyanti, M. A. 2015. "Konsep Gender dalam Prespektif Agama Islam. Dalam Jurnal IImiah Sains dan Teknologi. (90-91). 


\section{KETENTUAN PENULISAN ARTIKEL JURNAL KALPATARU}

1. Naskah berbahasa Indonesia yang disempurnakan bertemakan kesejarah yang meliputi hasil penelitian sejarah, pengajaran sejarah dan penelitian kebudayaan.

2. Naskah harus asli dan belum pernah dimuat dalam media lain. Naskah dapat berupa hasil penelitian/artikel kajian konseptual yang ditulis oleh perorangan dan atau kelompok.

3. Naskah ditulis dengan cara-cara yang sesuai dengan ketentuan penulisan artikel ilmiah menggunakan bahasa Indonesia yang baku, berupa ketikan, beserta soft file dalam CD-RW atau dengan mengirimkan email pada redaksi jurnal Kalpataru dengan alamat jurnalkalpatarusejarah@gmail.com, spasi tunggal, jenis huruf arial narrow ukuran 12, dengan panjang naskah antara 8-15 halaman pada kertas A4.

4. Artikel hasil penelitian memuat:

JUDUL

Nama Penulis

Abstrak

A. PENDAHULUAN

B. METODE PENELITIAN

C. HASIL DAN PEMBAHASAN

D. SIMPULAN

DAFTAR PUSTAKA
: XXX (HURUF KAPITAL)

: (disertai jabatan, institusi, dan email)

: (Bahasa Indonesia yang memuat 100-200 kata diikuti kata kunci, dengan jenis huruf arrial narrow dan ukuran huruf 11 serta dicetak miring).

: (memuat latar belakang masalah, tinjauan pustaka secara ringkas, masalah penelitian, dan tujuan penelitian).

5. Artikel Kajian Konseptual memuat:

JUDUL

Nama Penulis

Abstrak

PENDAHULUAN

Sub Judul

Simpulan

DAFTAR PUSTAKA
: (berisi simpulan).

: (berisi pustaka yang dirujuk dalam uraian naskah).

6. Referensi sumber dalam teks artikel ditulis dengan menggunakan side note, contoh (Jalaludin, 1991:79); sementara penulisan daftar pustaka disusun dengan ketentuan. Nama pengarang. Tahun terbit. Judul (dicetak miring). Kota terbit: Nama Penerbit. Contoh: Koentjaraningrat. 2010. Manusia dan Kebudayaan di Indonesia. Jakarta: Djambatan. Daftar pustaka hanya memuat pustaka/sumber yang dirujuk dalam uraian dan disusun menurut abjad tanpa nomor urut.

7. Naskah yang dimuat akan disunting kembali oleh redaksi tanpa mengubah isinya.

8. Naskah yang ditolak (tidak bisa dimuat) akan dikirim kembali ke penulis dengan pemberitahuan tertulis dari redaksi atau melalui email.

9. Penulis yang naskahnya dimuat akan mendapat 1 (satu) majalah nomor yang bersangkutan.

10. Kontak person: Muhamad Idris (081271498618); Eva Dina Chairunisa (082281267851); Jeki Sepriady (085269261780). 